e-journal Keperawatan (e-Kp) Volume 7 Nomor 1, Februari 2019

\title{
PENGARUH PEMBERIAN REBUSAN DAUN SALAM TERHADAP PENURUNAN KADAR ASAM URAT PADA PENDERITA GOUT ARTRITIS DI WILAYAH KERJA PUSKESMAS RANOTANA WERU
}

\author{
Vechya Z.L.P. Ndede \\ Wenda Oroh \\ Hendro Bidjuni \\ Program Studi Ilmu Keperawatan Fakultas Kedokteran \\ Universitas Sam Ratulangi \\ Email : vechyandede19@gmail.com
}

\begin{abstract}
Gout arthritis is one type of inflammation in the joints caused by the deposition of urate monosodium crystals in body tissues. To prevent or reduce uric acid levels increase, thats is by using natural plants like bay leaves. Bay leaves contains flavonoids which can reduce uric acid levels. The Purpose of this study to know the effect of giving bay leaves decoctions to decrease uric acid levels in patients with gout arthritis. Method of this study use experimental research design, with a pre-experimental approach. Sample with sampling techniques using total sampling with a total sample of 16 respondents. The result of the study using the dependent $t$ test with level if signficance 95\%, available significant value is 0,000 smaller than significant value 0,05 $(0,000<0,05)$. The Conclusion, of this study indicates effect of giving bay leaves decoctions to decrease uric acid levels in patients with gout arthritis in the working area of Ranotana Weru community health service center.
\end{abstract}

Keywords : Decoction Bay Leaves, Gout Arthritis

Abstrak : Gout artritis merupakan salah satu jenis radang sendi yang disebabkan oleh pengendapan kristal monosodium urat dalam jaringan tubuh. Untuk mencegah atau menurunkan kadar urat meningkat yaitu dengan memanfaatkan tumbuhan alami berupa daun salam. Daun salam mengandung flavonoid yang mampu menurunkan kadar asam urat. Tujuan untuk mengetahui pengaruh pemberian rebusan daun salam terhadap penurunan kadar asam urat pada penderita gout artritis. Metode menggunakan desain penelitian eksperimen, dengan pendekatan pre eksperimen. Sampel dengan teknik pengambilan sampel menggunakan metode total sampling dengan jumlah sampel sebanyak 16 responden. Hasil dengan menggunakan uji $t$ dependen dengan tingkat kemaknaan 95\%, didapatkan nilai $\rho-$ value 0,000 lebih kecil dari nilai signifikan 0,05 $(0,00<0,05)$. Kesimpulan, hasil penelitian ini menunjukkan terdapat pengaruh pemberian rebusan daun salam terhadap penurunan kadar asam urat pada penderita gout artritis di wilayah kerja Puskesmas Ranotana Weru Manado.

Kata kunci : Rebusan Daun Salam, Gout Artritis 
e-journal Keperawatan (e-Kp) Volume 7 Nomor 1, Februari 2019

\section{PENDAHULUAN}

Meningkatnya taraf hidup masyarakat terutama di negara maju dan kota besar membawa perubahan pada pola hidup setiap individu (Tumenggung, 2015). Perubahan pola kebiasaan hidup yang dapat menurunkan status kesehatan pada seseorang salah satunya ialah pola makan. Perubahan pola makan sehat yang mengandung banyak karbohidrat dan serat ke pola makan yang banyak mengandung protein, kalori, dan banyak mengandung purin dapat mengakibatkan kadar asam urat dalam darah meningkat dan akan menimbulkan penumpukan kristal asam urat. Peningkatan atau penumpukan asam urat dalam darah akan menyebabkan terjadinya penyakit gout artritis (Wirahmadi, 2013).

Prevalensi gout di dunia menurut World Health Organization (2018), mengalami kenaikan dengan jumlah 1370 $(33,3 \%)$. Prevalensi gout juga meningkat pada kalangan orang dewasa di Inggris sebesar 3,2 \% dan Amerika Serikat sebesar 3,9 \% (Kuo; Grainge; Zhang; Doherty, 2015). Di Korea prevalensi asam urat meningkat dari 3,49\% per 1000 orang pada Tahun 2007 menjadi 7,58 \% per 1000 orang pada tahun 2015 (Kim; kwak; Lee; Choe; Park, 2017). Hasil Riset Kesehatan Dasar (Riskesdas) tahun 2013, menyatakan bahwa prevalensi penyakit sendi di Indonesia berdasarkan diagnosis tenaga kesehatan (nakes) sebesar $11.9 \%$ dan di Provinsi Sulawesi Utara sebesar $10.3 \%$ (Riskesdas, 2013).

Gouth artritis merupakan salah satu jenis radang sendi atau inflamasi pada sendi yang disebabkan oleh pengendapan kristal monosodium urat dalam jaringan sinovisial dan jaringan lainnya (Neogi, 2011). Gout artritis akan menyebabkan kadar asam urat penderita meningkat dan juga penderita akan merasa nyeri, bengkak, kemerahan, dan hangat pada persendian. Apabila gejala yang timbul tidak diobati akan menyebabkan kerusakan pada sendi (Mandel, 2008).
Penanganan yang dilakukan untuk mencegah terjadinya peningkatan kadar asam urat dalam darah, antara lain pengaturan diet, menghindari makanan tinggi purin, konsumsi vitamin dan mineral yang cukup, olahraga rutin, berhenti merokok, pengendalian stres dan dapat diberikan obat-obatan untuk terapi farmakologi. Pengobatan lain yang dapat digunakan untuk mengatasi peningkatan kadar asam urat yaitu dengan pengobatan herbal (Sari \& Syamsiyah, 2017).

Masyarakat Indonesia menggunakan tanaman berkhasiat obat sebagai salah satu upaya untuk menanggulangi berbagai masalah kesehatan seperti gout artritis (Fariz; Sholihin; Fauzi; Rizki, 2018). Tanaman herbal yang berkhasiat mengatasi penyakit gout artritis yaitu rebusan daun salam (Utami \& Puspaningtyas, 2013). Daun salam mengandung flavonoid yang berfungsi untuk menurunkan kadar asam urat dalam darah dan membantu dalam pengeluaran asam urat melalui urin (Ekasari, 2018).

Hasil penelitian yang dilakukan oleh Andriani \& Chaidir (2016), di wilayah kerja Puskesmas Peninggahan kabupaten Solok untuk mengetahui aktivitas daun salam dalam menurunkan kadar asam urat dengan hasil sebelum pemberian daun salam rata-rata kadar asam urat 7,16 dan setelah diberikan daun salam kadar asam urat menurun menjadi 5,76. Menurut hasil penelitian yang dilakukan oleh Darussalam \& Rukmi (2016), dengan pemberian air rebusan daun salam dapat menurunkan kadar asam urat. Hal ini dikarenakan daun salam mengandung flavonoid yang berkhasiat untuk menurunkan kadar asam urat.

Hasil survey yang dilakukan pada
awal bulan oktober di Puskesmas Ranotana Weru didapatkan data penderita penyakit gout artritis pada bulan juli sampai dengan bulan agustus tahun 2018 berjumlah 106 orang, dengan pria berjumlah 42 dengan rentang usia 30-80 tahun orang dan wanita berjumlah 64 
orang dengan rentang usia 20-75 tahun. Dari hasil wawancara dengan beberapa masyarakat yang tinggal di wilayah kerja puskesmas Ranotana Weru, penyakit gout yang diderita mereka disebabkan karena pola konsumsi dan gaya hidup dan mereka hanya menggunakan obat famakologi untuk menurunkan kadar asam urat, serta mereka juga jarang menggunakan obat tradisional berupa daun salam untuk pengobatan gout atrritis.

Berdasarkan fenomena diatas peneliti tertarik untuk melakukan penelitian tentang "Pengaruh Pemberian Rebusan Daun Salam Terhadap Penurunan Kadar Asam Urat Pada Penderita Gout Artritis di wilayah kerja Puskesmas Ranotana Weru".

\section{METODE PENELITIAN}

Penelitian ini menggunakan jenis penelitian pre eksperimen, dengan metode one group pre-test post-test (Setiadi, 2013). Penelitian ini dilakukan di wilayah kerja Puskesmas Ranotana Weru pada tanggal 17 november 2018 dengan populasi sebanyak 106 responden. Pengambilan sampel dengan menggunakan rumus Supranto tahun 2002 dan didapatkan sampel sebanyak 16 responden sesuai dengan kriteria inklusi yaitu pasien yang tinggal di wilayah kerja puskesmas ranotana weru dan bersedia menjadi responden, pasien yang baru terdiagnosa gout artritis dan yang mengalami peningkatan kadar asam urat. kriteria ekslusi : klien yang tidak kooperatif saat mengikuti kegiatan, memiliki penyakit penyerta lainnya seperti diabetes, hipertensi, dan ginjal, dengan kadar asam urat yang pada pemeriksaan hasilnya normal, klien yang sudah lama terdiagnosa gout artritis dan mengkonsumsi obat gout artritis rutin. Penelitian ini menggunkan instrumen berupa lembar observasi dan SOP perebusan daun salam. Alat yang digunakan dalam penelitian ini ialah biosensor untuk mengukur kadar asam urat.
Teknik analisa data yang digunakan pada penelitian ini yaitu analisa univariat dan analisa bivariat. Analisa univariat pada penelitian ini bertujuan untuk Analisis univariat digunakan untuk mendapatkan distribusi frekwensi dari variabel yang diamati yaitu kadar asam urat sebelum dan sesudah pemberian intervensi. Sedangkan analisa bivariat dilakukan untuk mengetahui interaksi dua variabel yaitu untuk membuktian adanya pengaruh sebelum dan sesudah dilakukan pemberian rebusan daun salam terhadap perubahan kadar asam urat penderita gout artritis dengan menggunakan uji $\mathrm{T}$ berpasangan dengan batas signifikan yang digunakan adalah $95 \%$ atau tingkat kemaknaan 5\% $(\alpha$ $\leq 0,05)$.

\section{HASIL dan PEMBAHASAN}

A. Karakteristik Responden

Tabel 1. Distribusi frekuensi berdasarkan jenis kelamin responden di Puskesmas Ranotana Weru Tahun 2018

\begin{tabular}{lcc}
\hline $\begin{array}{c}\text { Jenis } \\
\text { Kelamin }\end{array}$ & $\mathrm{n}$ & $\%$ \\
\hline Laki-laki & 7 & 43,8 \\
Perempuan & 9 & 56,3 \\
\hline Total & 16 & 100,0 \\
\hline
\end{tabular}

Sumber : Data Primer, 2018

Berdasarkan tabel 1, menjelaskan bahwa dari 16 responden $(100 \%)$, didiapati mayoritas responden yang menderita gout artritis yaitu berjenis kelamin perempuan sebanyak 9 responden $(56,3 \%)$. 
e-journal Keperawatan (e-Kp) Volume 7 Nomor 1, Februari 2019

Tabel 2. Distribusi frekuensi berdasarkan umur responden di Puskesmas Ranotana Weru Tahun 2018

\begin{tabular}{lcc}
\hline \multicolumn{1}{c}{ Umur } & $\mathrm{n}$ & $\%$ \\
\hline $36-45$ tahun & 4 & 25,0 \\
$46-55$ tahun & 7 & 43,8 \\
$56-60$ tahun & 5 & 31,3 \\
\hline Total & 16 & 100,0 \\
\hline
\end{tabular}

Sumber : Data Primer, 2018

Berdasarkan tabel 2, menjelaskan bahwa dari 16 responden, didapati mayoritas responden yang menderita gout artritis terbanyak berada pada rentang usia 46-55 tahun dengan jumlah responden 7 orang $(43,8 \%)$ dan yang paling sedikit pada rentang usia 36-45 tahun yaitu sebanyak 4 responden $(25,0 \%)$.

\section{B. Analisa Univariat}

Tabel 3. Distribusi Kadar Asam urat sebelum dan sesudah diberikan rebusan daun salam

\begin{tabular}{lcccc}
\hline $\begin{array}{c}\text { Kadar Asam } \\
\text { Urat }\end{array}$ & $\mathrm{n}$ & mean & median & Min-max \\
\hline $\begin{array}{l}\text { Pre-test } \\
\text { (Hari ke-1) }\end{array}$ & 16 & 9,18 & 9,25 & $7,20-11,20$ \\
$\begin{array}{l}\text { Post-test } \\
\text { (Hari ke-7) }\end{array}$ & 16 & 7,97 & 7,85 & $6,50-10,30$ \\
\hline
\end{tabular}

Sumber : Data Primer 2018

Berdasarkan tabel 3, didapati dari 16 responden, nilai rata-rata (mean) untuk pemeriksaan kadar asam urat pretest adalah 9,18 mg/dL dan pemeriksaan kadar asam urat posttest adalah 7,97 mg/dL. Kemudian untuk nilai tengah (median) dari pemeriksaan kadar asam urat pretest yaitu 9,25 $\mathrm{mg} / \mathrm{dL}$ dan posttes 7,85 $\mathrm{mg} / \mathrm{dL}$. Sedangkan untuk nilai terendah (minimum) dari pemeriksaan kadar asam urat pretest yaitu $7,20 \mathrm{mg} / \mathrm{dL}$ dan nilai tertinggi (maximum) yaitu $11,20 \mathrm{mg} / \mathrm{dL}$. Pemeriksaan kadar asam urat posttest untuk nilai terendah (minimum) yaitu 6,50 $\mathrm{mg} / \mathrm{dL}$ dan nilai tertinggi (maximum) yaitu $10,30 \mathrm{mg} / \mathrm{dL}$.

\section{Analisa Bivariat}

Tabel 4. Pengaruh rebusan daun salam terhadap penurunan kadar asam urat

\begin{tabular}{lcccc}
\hline $\begin{array}{c}\text { Kadar Asam } \\
\text { Urat }\end{array}$ & $\mathrm{n}$ & mean & SD & $\rho$-value \\
\hline $\begin{array}{l}\text { Pre-test } \\
\text { (Hari ke-1) }\end{array}$ & 16 & 9,18 & 1,241 & \\
$\begin{array}{l}\text { Post-test } \\
\text { (Hari ke-7) }\end{array}$ & 16 & 7,97 & 1,269 & 0,000 \\
\hline
\end{tabular}

Sumber : Data primer 2018

Berdasarkan tabel 9, diketahui nilai rata-rata kadar asam urat responden sebelum pemberian daun salam ialah sebesar $9,18 \mathrm{mg} / \mathrm{dL}$ dengan standar deviasi 1,241. Pada pengukuran kadar asam urat sesudah pemberian rebusan daun salam, didapatkan nilai rata-rata kadar asam urat sebesar 7,97 mg/dL dengan standar deviasi 1,269. Dari hasil uji $\mathrm{T}$ berpasangan didapatkan nilai $p=0,000$ atau nilai $p<\alpha$ atau 0,05. Dengan demikian, maka $\mathrm{H}_{0}$ ditolak dan $\mathrm{Ha}$ diterima. Hal ini menunjukkan ada ada pengaruh dengan mengkonsumi rebusan daun salam secara teratur dan sesuai prosedur dapat menurunkan kadar asam urat pada penderita gout artritis.

\section{Jenis kelamin}

Hasil penelitian ini sejalan dengan penelitian yang dilakukan oleh Yankusuma \& Putri (2016) yang berjudul pengaruh pemberian rebusan daun salam terhadap penurunan kadar asam urat di desa Malanggaten Kecamatan Kebakkramat dengan jumlah sampel 20 orang dengan mayoritas berjenis kelamin perempuan yaitu sebanyak $66,7 \quad \%$ sedangkan responden berjenis kelamin laki-laki sebanyak 33,3\%.

Hasil penelitian lainnya yang dikemukakan oleh Darusalam \& Rukmi (2016), yang berjudul peran rebusan daun salam dalam menurunkan kadar asam urat dengan jumlah sampel 24 orang didapatkan mayoritas berjenis kelamin perempuan sebanyak 20 orang $(83,3 \%)$, sedangkan berjenis kelamin laki-laki sebanyak 4 orang $(16,7 \%)$. 
Toding et al. (2015) menyatakan bahwa jenis kelamin merupakan salah satu faktor yang mempengaruhi kejadian gout artritis. Hal ini dikarenakan pada perempuan terjadi penurunan hormon estrogen pada waktu memasuki usia 45 tahun sehingga resiko terjadinya gout artritis meningkat.

\section{Umur}

Hasil penelitian ini sejalan dengan penelitian yang dilakukan oleh Darussalam \& Rukmi (2016) dengan judul penelitian peran rebusan daun salam (sizygium polyanthum) dalam menurunkan kadar asam urat, dengan jumlah sampel 24 orang dengan mayoritas usia antara 50-59 tahun. Agromedia dalam (Yankusuma \& Putri, 2016), mengatakan bahwa usia sangat mempengaruhi kadar asam urat seseorang. Pada laki-laki lebih rentan terkena asam urat di usia 30 tahun keatas hal ini disebabkan karena laki-laki tidak memiliki hormon estrogen sedangkan pada wanita lebih rentan terkena asam urat saat usia 45 tahun hal ini disebabkan karena pada wanita mulai mengalami penurunan level esterogen. Sesuai dengan data yang didapatkan saat penelitian mayoritas responden yang menderita asam urat berada pada rentang usia 45-55 tahun, dimana pada rentang usia ini sudah memasuki masa meanopause dan terjadi penurunan level estrogen pada wanita serta penurunan metabolisme tubuh.

\section{Kadar asam urat sebelum pemberian rebusan daun salam}

Penelitian ini sejalan dengan penelitian yang dilakukan oleh Andriani \& Chaidir (2016), dengan hasil rerata kadar asam urat sebelum diberikan rebusan daun salam adalah 7,16. Pada wanita umumnya mengalami peningkatan asam urat pada usia 45 tahun yang disebabkan karena terjadi penurunan level estrogen. Pada penelitian lain yang dilakukan oleh Ardhiyanti; Rosalina; Purwaningsih (2014), yang berjudul pengaruh pemberian rebusan daun salam (sizygium polyanthum) terhadap penurunan kadar asam urat dengan hiperusemia di desa Leyangan Kecamatan Ungaran Timur, didapatkan rerata kadar asam urat sebelum pemberian rebusan daun salam adalah 8,21 mg/dL. Menurut Sari \& Syamsiyah (2017), ada beberapa faktor yang dapat mempengaruhi peningkatan kadar asam urat pada seseorang seperti obesitas, konsumsi alkohol terlalu banyak, obatobatan (diuretik thiazide, cyclosporine, aspirin dosis rendah dan obat kemoterapi), serta kondisi medis (diabetes, hipertensi, gangguan fungsi ginjal) Kadar asam urat normal pada pria adalah $3,0-7,0 \mathrm{mg} / \mathrm{dL}$ dan pada perempuan $2,4-6,0 \mathrm{mg} / \mathrm{dL}$.

Berdasarkan hasil penelitian, didapatkan bahwa kadar asam urat yang dimiliki responden yang tinggal di wilayah kerja Puskesmas Ranotana Weru kadar asam uratnya cukup tinggi. Peningkatan kadar asam urat ini disebabkan karena bertambahnya usia, pola makan yang tidak sehat berupa terlalu banyak mengkonsumsi makan yang mengandung purin, dan kurang beraktivitas.

\section{Kadar asam urat sesudah pemberian rebusan daun salam}

Hasil penelitian ini sejalan dengan penelitian yang dilakukan oleh Andriani \& Chaidir (2016), dengan hasil penelitian yang menunjukkan rerata kadar asam urat sesudah pemberian rebusan daun salam yaitu 5,76 $\mathrm{mg} / \mathrm{dL}$. Hal ini karena kandungan yang terdapat pada daun salam yaitu flavonoid yang berfungsi menghambat kerja enzim xaintin oksidase dalam pemberntukan adam urat, serta berfungsi sebagai diuretik untuk membantu pengeluaran asam urat dalam darah melalui urin.

Hasil penelitian, menunjukkan bahwa terjadi penurunan kadar asam urat sesudah pemberian rebusan daun salam pada responden di wilayah kerja Puskesmas Ranotana Weru. Hal ini karena kandungan yang terdapat pada daun salam dapat menurunkan kadar asam urat dan juga karena kepatuhan dan keteraturan 
responden dalam meminum air rebusan daun salam selama 1 minggu dengan frekuensi 1 kali sehari (7 hari).

\section{Pengaruh pemberian rebusan daun salam terhadap penurunan kadar asam urat pada penderita gout artritis}

Berdasarkan hasil uji $\mathrm{T}$ berpasangan menunjukan bahwa terdapat perbedaan rerata kadar asam urat sebelum dan sesudah diberikan rebusan daun salam. Hasil menunjukan terjadi penurunan kadar asam urat setelah responden diberikan rebusan daun salam selama satu minggu. Nilai rata-rata kadar asam urat responden sebelum diberikan rebusan daun salam yaitu $9,18 \mathrm{mg} / \mathrm{dL}$ dan nilai rata-rata kadar asam urat setelah pemberian rebusan daun salam yaitu 7,97 mg/dL. Dari hasil uji T berpasangan didapatkan nilai $p$ value adalah 0,000 yang berarti terdapat pengaruh sebelum dan sesudah pemberian rebusan daun salam yang dilakukan selama satu minggu.

Hasil penelitian ini sejalan dengan penelitian yang dilakukan oleh Andriani \& Chaidir (2016) yang berjudul pengaruh pemberian air rebusan daun salam (sizygium polyanthum) terhadap penurunan kadar asam urat di Puskesmas Paninggahan Kabupaten Solok. Didapatkan hasil signifikan (p) 0,000 $(<\alpha$ $0,05)$ terdapat pengaruh pemberian rebusan daun salam terhadap penurunan kadar asam urat.

Menurut Ekasari (2018), kandungan yang terdapat pada daun salam berupa flavonoid dapat menghambat kerja enzim xiantin oksidase yang berperan dalam oksidasi hipoxantin menjadi xantin dan selanjutnya pembentukan asam urat dari xantin. Dengan terhambatnya kerja enzim xantin oksidase maka pembentukan asam urat juga akan terhambat. Hasilnya tidak akan terjadi peningkatan kadar asam urat dalam darah. Menurut Fariz et al. (2018) flavonoid juga berfungsi sebagai diuretik yang dapat membantu pengeluaran asam urat melalui urin.
Penelitian ini sejalan dengan penelitian yang dilakukan oleh Febriyanti \& Andika (2018), yang berjudul pengaruh pemberian rebusan daun salam (syzigium polyanthum) terhadap penurunan kadar asam urat pada lansia, didapatkan nilai rata-rata kadar asam urat sebelum diberikan rebusan daun salam yaitu 8,14 dan nilai rata-rata kadar asam urat sesudah diberikan rebusan daun salam yaitu 4,24 dengan nilai $p$ value $0,000(<\alpha 0,05)$, yang berarti pemberian rebusan daun salam dapat menurunkan kadar asam urat pada lansia di kelurahan Kuranji Kota Padang.

Berdasarkan penelitian yang dilakukan selama 7 hari dengan memberikan rebusan daun salam sekali sehari pada setiap responden dapat disimpulkan bahwa dengan mengkonsumsi rebusan daun salam secara teratur dan sesuai dengan aturan yang dianjurkan pada waktu penelitian dapat menurunkan kadar asam urat.

\section{SIMPULAN}

Hasil penelitian ini didapatkan bahwa dengan mengkonsumsi rebusan daun salam secara teratur dan sesuai dengan dosis yang dianjurkan yaitu $200 \mathrm{ml}$ atau 1 gelas air rebusan daun salam di minum sekali dalam sehari dapat menurunkan kadar asam urat pada penderita gout artritis.

\section{DAFTAR PUSTAKA}

Andriani, A., \& Chaidir, R. (2016, Mei 17). Pengaruh pemberiaan air rebusan daun salam (syzygium polyanthum) terhadap penurunan kadar asam urat. Jurnal Ipteks Terapan, 10(2), 112-119. Oktober 02 , 2018. http://www.ejournal.kopertis10.or.id

Ardhiyanti, N. W. R., Rosalina, R., \& Purwaningsih, P. (2014, Agustus). Pengaruh pemberian air rebusan daun salam (syzigium polyanthum w) terhadap penurunan kadar asam urat dengan hiperurisemia di desa Leyangan kecamatan Ungaran Timur 
e-journal Keperawatan (e-Kp) Volume 7 Nomor 1, Februari 2019

kabupaten Semarang. Medisains, 17(2). Desember 10, 2018. http://www.portalgaruda.org

Darussalam, M., \& Rukmi, D.K. (2016, Agustus). Peran air rebusan daun salam (syzygium polyanthum) dalam menurunkan kadar asam urat. Media Ilmu Kesehatan, 5(2), 83-91. Oktober $\quad 2018$. http://www.ejournal.unjaya.ac.id

Ekasari, W, 2018. Tanaman dan Kesehatan, Terapi Alternatif Tiga Penyakit Utama dengan Bukti Ilmiah. Indomedika Pustaka: Sidoarjo

Fariz, A., Sholihin, M.A., Fauzi, R., \& Rizki, M.I. (2018, Februari). Riview: tanaman obat yang berefek sebagai antigout. Jurnal Pharmascience, 2018, 5 (1), 22-31. Oktober 02, 2018. http://jps.www.unlam.ac.id

Febriyanti, M. A. (2018, April). Pengaruh pemberian rebusan daun salam (syzigium polyanthum) terhadap kadar asam urat pada lansia. Menara Ilmu 12(10). Desember 11, 2018. http://www.umbs.ac.id

Kim, J. W., Kwak, S. G., Lee, H., Kim, S. K., Choe, J. Y., \& Park, S. H. 2017. Prevalence and incidence of gout in Korea: data from the national health claims database 2007-2015. Rheumatology international, 37(9), 1499-1506. Oktober 04, 2018.

Kuo, C. F., Grainge, M. J., Zhang, W., Doherty, M. (2015). Global epidemiology of gout: prevalence, incidence and risk factors. Nature Reviews Rheumatology, 11 (11), 649. Oktober $\quad 02,2018$. http://www.nature.com/articles/nrrhe um.2015.91

Mandell, F. B. (2008, Juli). Clinical manifestations of hyperuricemia and gout. Cleveland Clinic Journal of Medicine, 75 (5), S5-8. September 28 http://www.europepmc.org 2018.

Neogi, T. (2011, Februari 03). Gout. New England Journal Of Medicine, 364 (5), 443-452. Oktober 08, 2018. http://www.nejm.org

Puskesmas Ranotana Weru. (2018). Profil Puskesmas Sario, Sistem Informasi Kesehatan

Riskesdas, 2013. Riset Kesetahan Dasar Tentang Penyakit Sendi. Oktober 02, 2018. www.litbang.depkes.go.id

Sari, Y. A \& Syamsiyah, N. (2017). Berdamai Dengan Asam Urat. Tim Bumi Medika: Jakarta

Setiadi. (2013). Konsep dan Praktik Penulisan Riset Keperawatan Edisi 2. Graha Ilmu: Yogyakarta

Toding, M.N., Ratag, B.T., \& Pinontoan, O.R. (2015). Analisis faktor-faktor risiko kejadian gouthy arthritis di wilayah kerja puskesmas bahu kota manado. Oktober 02, 2018. http://www.ejournalhealth.com

Tumenggung, I. (2015, Agustus). Hubungan pola makan dengan kejadian gout arthritis di rsud toto kabila kabupaten bone bolango. Journal Health And Nutrition, 1(2), 1-12. September 28, 2018. http://www.jurnal.poltekkesgorontalo .ac.id

Utami, P. \& Puspanintiyas E.D. (2013). The Miracle of Herbs. PT. Agromedia Pustaka: Jakarta

Wirahmadi, I. K. N. (2013). Pengaruh pemberian rebusan daun sirsak terhadap nyeri pada penderita gout di kelurahan genuk barat kecamatan Unggaran barat kabupaten Semarang. 
e-journal Keperawatan (e-Kp) Volume 7 Nomor 1, Februari 2019

WHO Health Organization. (2018, Juni). WHO Methods and Data SourcesFor Global Burden Of Disease Estimates 2000-2016.

Yankusuma, D., \& Putri, P. (2016, Maret). Pengaruh pemberian rebusan daun salam terhadap penurunan kadar asam urat di desa malanggaten kecamatan kebakkramat kabupaten karanganyar. Jurnal Ilmu Kesehatan Kosala, 4 (1), 90-96. Oktober 02, 2018.

http://www.ejournal.akperpantikosal a.ac.id 